\title{
Pembelajaran Kaligrafi Arab untuk Meningkatkan Maharah Al-Kitabah
}

\author{
Muhammad Fauzi \\ Universitas Islam Negeri Sunan Ampel Surabaya \\ Email: muhammadfauzi143@gmail.com \\ Muhammad Thohir \\ Universitas Islam Negeri Sunan Ampel Surabaya \\ Email: muhammadthohir@uinsby.ac.id
}

\begin{abstract}
Abstrak
Problematika yang terjadi di kalangan peserta didik sering mengalami kesulitan Ketika menulis huruf huruf arab yang baik dan benar ini terjadi dikarenakan Ketika proses menulis tidak ada penekanan dari pengajar kepada peserta didik dan juga karena didalam menulis memilki hubungan antara proses berfikir dan proses expesif keindahan, Materi keterampilan menulis (maharah al-kitabah) diberikan agar siswa dapat membentuk alphabet dan mengeja. Selain itu, juga dapat membantu siswa dalam menyalurkan fikiran dan perasaan melalui tulisan. Meningkatkan maharah al-kitabah terdapat beberapa macam teknik salah satu adalah khat (kaligrafi). Khat merupakan proses menulis rapi, keindahan, sehingga dalam pembelajaran khat peserta didik tidak hanya menulis menulis huruf dan membentuk kata serta kalimat saja, tetapi juga menyentuh aspek estetika atau keindahan, sehingga membuat mereka nyama dan betah untuk terus menulis Oleh karena itu, tujuan pembelajaran khat adalah agar para peserta didik terampil menulis huruf-huruf dan kalimat bahasa Arab dengan benar dan indah. Metode pembelajaran yang cocok untuk kaligrafi yautu metode demonstrasi, metode menjiplak, metode ceramah, metode penugasan dan metode drill.
\end{abstract}

\section{Kata Kunci: Kaligrafi, Keterampilan Menulis, Pembelajaran Bahasa Arab}

\begin{abstract}
Problems that occur among students often experience difficulties When writing Arabic letters correctly and correctly this occurs because when the writing process there is no emphasis from the instructor to students and also because in writing have the relationship between the thought process and the process of beauty expesive beauty, material writing skills (Maharah al-Kitabah) is given so that students can form alphabets and spell. In addition, it can also help students channel their thoughts and feelings through writing. Increasing maharah alkitabah there are several kinds of techniques one of which is khat (calligraphy). Khat is a neat writing process, so that in learning khat students not only write
\end{abstract}


letters and form words and sentences, but also touch on aesthetic or beauty aspects, making them comfortable and at ease to continue writing. Therefore, the purpose of learning khat is that the students are skilled at writing Arabic letters and sentences correctly and beautifully. Learning method that is suitable for calligraphy is the demonstration method, the tracing method, the lecture method, the assignment method and the drill

Keywords: Calligraphy, Writing Skills, Arabic Teaching

\section{ملخص}

غالبًا ما تواجه المشكلات التي تحدث بين الطلاب صعوبات عند كتابة الحروف العربية بشكل صحيح وصحيح يحدث هذا لأنه عندما لا يكون هناك أي تأكيد من المعلم على الطلاب أثناء عملية الكتابة وأيضًا لأن العلاقة بين عملية التفكيروعملية الجمال المفرطة ، مادة مهارات الكتابة (مهارة الكتاب) بحيث يمكن للطلاب تكوين الحروف الهجائية والتهجئة. بالإضيافة إلى ذلك ، يمكن أن يساعد الطلاب على توجياه أفكارهم ومشاعرهم من خلال الكتابة. زيادة مهارة الكتاب هناك عدة أنواع من التقنيات أحدها القات. القات هي عملية كتابة متقنة ، بحيث لا يتعلم الطلاب في القات كتابة الحروف وتكوين الكلمات والجمل فحسب ، بل يتطرقون أيضًا إلى الجوانب الجمالية أو الجمالية ، مما يجعلههم مرتاحين ويسهل عليهم مواصلة الكتاباة. وبالتالي ، فإن الغرض من تعلم القات هو أن الطلاب ماهرون في كتابة الحروف والجمل العربية بشكل صحيح وجميل. طربقة التعلم المناسبـة للخط هي طريقة العرض وطريقة التتبع وطريقة المحاضرة وطريقة التعيين وطريقة الحفر.

\section{الكلمة الرئيسية : الخط، مهارة الكتابة، تعليم اللغة العربية}

\section{Pendahuluan}

Bahasa Arab merupakan salah satu mata pelajaran yang hampir ada disetiap jenjang pendidikan, mata pelajaran Bahasa Arab juga berada di posisi penting dalam jenjang Pendidikan karena sebagai kunci ilmu keislaman, maka sangat penting sebagai umat islam untuk mempelajari Bahasa Arab dengan baik dan benar.

Sebagaimana yang kita ketahui dalam belajar bahasa Arab, peserta didik harus dapat menguasai empat maharah yaitu maharah al-istima', kemudian maharah al- kalam, maharah al-qiroah dan maharah al-kitabah. Dari ke empat keterampilan tersebut saling berkaitan yang bertujuan untuk menggembangkan kemampuan peserta didik dalam menggunakan 
bahasa, baik secara lisan atau tulisan. Diantara keterampilan dalam berbahasa yaitu keterampilan menulis (maharatul al kitabah). Keterampilan ini sangat diperlukan oleh peserta didik untuk menyalin, mencatat atau untuk menyelesaikan tugas tugas lainnya, kemudian dalam kehidupan sehari hari seperti mengirim surat, mengisi formulir, atau membuat catatan agenda penting.

Menurut Hermawan maharah al-kitabah adalah kemampuan untuk mengungkapkan isi pikiran atau mendeskripsikan sesuatu dimulai dari aspek yang sederhana seperti menulis kata sampai mengarang. Sedangkan Sunandar dan Iskandarwassid berpendapat bahwa maharah al-kitabah merupakan salah satu keterampilan yang paling tinggi tingkat kesulitannya bagi peserta didik dibandingkan dengan keterampilan lainnya ${ }^{1}$

Terdapat beberapa kategori yang tidak dapat dipisahkan agar meningkatkan maharah al-kitabah yang pertama adalah Imla', kedua kaligrafi (Khat), dan ketiga mengarang (Insya'). Dan dari salah satu problematika bagi peserta didik Indonesia mengalami kesulitan pada tahap yang ke dua yaitu kaligrafi (Khat), Karena pada kategori ini cenderung tidak mendapat perhatian lebih dari para pengajar maupun peserta didik saat belajar bahasa arab, sehingga mengakibatkan tulisannya keluar dari ketentuan disetiap bentuk font arab dan tidak memiliki keindahan. Untuk menjelaskan bagaimana pentingnya kaligrafi sebagai salah satu faktor meningkatkan keterampilan menulis arab, maka penulis akan membahas Apa pengeritan kaligrafi Bagaimana langkah langkah pembelajaran kaligrafi untuk meningkatkan maharah khitabah.

\section{Pengertian Kaligrafi}

Kaligrafi atau khat memilki peran penting terhadap perkembang kebudayan islam yang memilik aspek sejarah yang kuat, sehingga mendapat perhatian lebih dari para penulis sejarah dan kebudayaan karena selama 14 abad lebih kaligrafi memainkan peran dominan yang mengisi hiruk pikuk perjalanan seni Islam secara menyeluruh.

Kata kaligrafi atau dalam bahasa Arabnya khath sering dikaitkan dengan keahlian menulis indah huruf atau secara bentuk visualnya (Khath Hasan Jamîl), bukan isi atau materi. kata kaligrafi dari bahasa Inggris:

${ }^{1}$ Khoirotun Nieemah. Implementasi Media Papan Mahir Bahasa Arab Dalam Pembelajaran Maharoh Kitabah. Jurnal Dar el-ilmi Vol.5 No.2 Oktober 2018, diakses tanggal 21 Oktober 2019. Hal. 94. 
calligraphy, yang berasal dari bahasa Latin: kalios, yang berarti: indah. dengan kata: graphein, yang berarti: tulisan, sehingga kata kaligrafi dapat diartikan dengan tulisan indah atau keahlian menulis indah ${ }^{2}$

Menurut Srajudin A.R dalam ayat tersebut disamping mengandung perintah menulis, lebih jelasnya beliau berkata:

"Yang lebih mengagumkan bahwa membaca dan menulis merupakan perintah pertama dalam wahyu tersebut. Dapat dipastikan bahwa kalam atau pena memiliki kaitan erat dengan seni penulisan kaligrafi. Jika kalam tersebut sebagai diatas. Maka ia adalah sarana AlKhaliq dalam rangka memberikan petunjuk kepada manusia. Ini membuat gambaran yang jelas, bahwa kaligrafi memdominasi tempat tertua dalam peratuaran sejarah Islam itu sendiri. ${ }^{3}$

Definisi Kaligrafi Dari Beberapa Ahli

1. Menurut Syaikh Syamsuddin Al-Ahfani kaligrafi adalah ilmu yang mempelajari beragam bentuk tunggal, pisah dan tata letaknya. Serta cara atau metode merangkainya menjadi susunan kata atau cara penulisan di atas kertas. (Al-akfani -Irsyadul Qasid).

2. Menurut Yaqut Al-Musta'shimy kaligrafi adalah seni arsitektur yang dieksoresikan lewat keterampilan.

3. Menurut Ubaid bin Ibad kaligrafi adalah duta atau utusan dari tangan, dan pena adalah dutanya. ${ }^{4}$

Dari pengertian di atas dapat diketahui bahwa adanya perbedaan. Di antara perbedaannya adalah bahwa dalam kaligrafi dibutuhkan aturan main khusus dalam pembentukan tiap hurufnya, persambungan tiap huruf maupun penyusunannya dalam kata maupun kalimat. Selain itu adalah adanya unsur keindahan, konsistensi bentuk, serta rumus-rumus yang telah lazim digunakan

Kata khat sebagai masdar dari Khaththa (خط ) mempunyai beberapa arti antara lain: menulis/tulisan, memberi garis (tanda), menggaris

${ }^{2}$ Khath secara istilah menurut Syeikh Syamsuddin Al-Akfânî sebagaimana dikutip oleh Al-Qalqasyandi bahwa: "Khath/Kaligrafi adalah suatu ilmu yang dari ilmu itu dapat mengetahui bentuk-bentuk huruf tunggal, letak-letaknya dan cara-cara merangkainya menjadi sebuah tulisan yang tertata, atau huruf-huruf yang ditulis pada garis, bagaimana cara menulisnya, menentukan mana yang tidak perlu ditulis, mengganti huruf yang harus diganti dalam ejaannya dan dengan huruf apa digantinya".

3 Sirajuddin AR. Seni Kaligrafi Islam, (Jakarta: Amzah, 2016), h. 5.

${ }^{4}$ https://essay.co.id/pengertian-kaligrafi-dan-jenisnya-lengkap/ 
bawahi, merencanakan dan lain-lain. ${ }^{5}$ Selain kitabah disebut dengan khath juga disebut dengan imla, Kata imla' adalah bentuk masdar dari amla (املى) yang berarti mendiktekan/dikte (التلقين)

Teknik menulis kaligrafi bukanlah sesuatu yang asal-asalan, ada alasan tertentu dibalik setiap teknik, ada geometri yang akurat, ada kaidah-kaidah ketat di dalamnya, ada kesepakatan tidak tertulis diantara para seniman kaligrafi: seindah, sevariatif, serumit apapun kaligrafi, jangan sampai mengubah makna dan teks asli Alquran. Bahkan di awal perkembangan pencatatan Alquran ke dalam media tulis, kaligrafi difungsikan sebagai alat bantu untuk membaca Al-quran agar tidak salah ucap yang bisa mengakibatkan perubahan makna. Diantara sumbangan kaligrafi untuk pencatatan Alquran adalah munculnya tanda baca dan pewarnaan tertentu supaya orang tidak salah dalam membaca Alquran. Kaligrafi untuk tujuan pencatatan Al-Quran pertama kali dibuat di masa kepemimpinan Abdul Malik bin Marwan. ${ }^{7}$

Pada mulanya, khat dengan kitabah memiliki makna yang sama. Pada perkembangan selanjutnya penggunaan khat berbeda dengan kitabah, makna kitabah lebih luas dari pada khat. Khat merupakan bagian dari kitabah yang memiliki karakterristik khusus, yaitu mengandung nilai estetika, bentuknya yang sudah baku memiliki kaidah yang harus diikuti. ${ }^{8}$

Dari pengertian tersebut khat sangat berkaitan dengan kitabah selain harus sesuai dengan kaidah khattiyah, dan juga harus sesuai dengan kaidah imla'iyah. Ketika menulis maka kita harus mengetahui huruf huruf yang kita ditulis sesuai denngan yang kita ucapkan, adakalanya diupakan namun tidak ditulis, dan adakalanya tidak diucapkan namun ditulis. Selain itu, khat juga memperjelas pesan yang disampaikan oleh pengirim pesan kepada penerima pesannya. Maka selain kaidah khat, kaidah imla dan inysa' juga sangat penting untuk dikaji.

\section{Tujuan belajar Khat/Kaligrafi Arab}

Ada beberapa tujuan pembelajaran kaligrafi, antara lain:

${ }^{5}$ Ahmad Warson Munawir, al-Munawir Qamus Arab Indonesia (tt).h. 378-379.

${ }^{6}$ Lihat Ahmad Warson Munawir, al-Munawir Qamus Arab Indonesia (tt), h. 14571458

${ }^{7}$ Annemarie Schimmel, Calligraphy and Islamic Culture, (London: I.B Tauris E Co Ltd, 1990), hlm. 4

8 Zakiyah mufida Pengembangan Bahan Ajar Khat Riq'ah Berbasis Kitabah Di Prodi PBA Semester II Skripsi, (UIN Sunan Kalijaga Yogyakarta 2016-2017) hlm 19

El-Ibtikar Vol 9 No 2 Desember 2020 
1. Sebagai kontribusi dalam pembelajaran qiraah, karena berkaligrafi merupakan proses untuk menyempurnakan membaca, apa lagi untuk tahap awal.

2. Membiasakan siswa untuk menulis dengan bentuk yang jelas bisa dibaca, dapat dibedakan antara bentuk huruf satu dengan huruf yang lain

3. Kecepatan dalam menulis tampa melewati batas, sehingga kecepatan tidak akan menghilangkan kaindahan kaligrafi.

4. Membiasakan murid mengendalikan gerakan tanggannya dengan mudah, ringan dan memelihara keterampilan menulis dengan indah

5. Membiasakan murid agar memilik kebiasaan baik seperti kebersihan, dan menjauhkan dari kebiasaan buruk seperti meletakan pena di mulut, mengotori pakaian atau catatan

6. Kecenderungan siswa terhadap gerakan perbuatan karena sesuai dengan semangat dan kegemarannya terhadap meniru ${ }^{9}$

7. Memudahkan orang lain untuk membaca setiap tulisan

8. Membantu seseorang mencapai kesuksesan profesi dan social

9. Agar para membaca tidak mudah leleh melihat tulisan kita Menjaga jarak antara huruf satu dengan yang lain antara kalimat satu dengan kalimat yang lain.

10. Teliti pada tiap posisi huruf, menggoreskan komposisi dari setiap bentuk sudut dan lengkungan

Terdapat tiga aspek dalam pembelajaran khat yaitu merancang, melaksanakan dan mengevaluasi. Berikut akan dijelaskan aspek pembelajaran kaligrafi: ${ }^{10}$

1. Merancang pembelajaran khat

Sebelum memulai pembelajaran khat pendidik hendaknya menyiapkan rancangan pembelajaran yangmeliputi beberapa unsur. Seperti: tujuan pelajaran, materi pelajaran, sarana-sarana pembantu,dan tahap-tahap penyampaian pelajaran

2. Pelaksanaan pembelajaran khat

${ }^{9}$ Falla Shalih Husain al-Jaburi dan Huda Muhammad Salman al-Qaisi, " Al-Khatt al arbai, Ma'ayir Jaudatih Wa Asalibu Tadririsih dalam majalah al buhus at tarbawiyyah wa anNafsiyah, No. 34,2012,hlm. 448

${ }^{10}$ Khoirotun Nieemah Khat Dalam Menunjang Kemahiran Kitabah Bahasa Arab. Jurnal Dar el-ilmi Vol.5 No.2 Oktober 2018, diakses tanggal 21 Oktober 2019, hal. 40 


\section{a. Langkah awal}

Pembelajaran khat pada langkah awal ini dimulai di kelas satu dan dua SD/MI, langkah yang harus ditempuh oleh seorang pendidik adalah memotivasi mereka untuk meniru sebisanya tidak perlu dituntut supaya detail dan indah. Hendaknya guru mewajibkan peserta didik menggunakan alat-alat penjelas dan warna.Langkah kedua

b. Langkah kedua

Pembelajaran khat pada langkah kedua ini dimulai di kelas tiga dan empat, pada langkah kedua ini peserta didik membutuhkan pengarahan seperti cara menyempurnakan setiap bentuk huruf seumpama gigi sin, kepala ha dan lengkungan-lengkungan huruf tertentu dan seterusnya. Mereka harus selalu diberi motivasi, karena mempunyai buku tulis tersendiri untuk Khat Naskhi yang digunakan untuk membaca dan menulis setiap mata pelajarannya. Pada periode ini, peserta didkk lebih banyak diarahkan kepada cara menggunakan tangan dan memegang $\mathrm{kalam} /$ pena secara betul.

\section{c. Langkah ketiga}

Pembelajaran khat pada langkah ketiga ini dimulai di kelas lima dan enam, pada langkah ketiga ini peserta didik diharapkan memiliki buku tulis Khat Riqeah yang merupakan materi baru. Tangannya yang telah terlatih menulis Khat Naskhi akan sangat membantunya dalam mempelajari jenis kaligrafi baru ini. Selain itu, pada langkah ini, harus ada peningkatan ketajaman menelaah, pengetahuan tentang hubunganhubungan dan perbandingan antara bentu-bentuk huruf serta tuntutan agar murid memperbagus kaligrafinya untuk membangkitkan ketajaman rasa seni dalam jiwanya

d. Langkah keempat

Pembelajaran khat dimulai di tingkat SLTP/MTs kelas tujuh dan delapan, pada langkah keempat ini peserta didik harus memiliki buku tulis Khat dan diwajibkan mengerjakan tugas-tugas menulis Khat dibuku tersebut agar tangannya terlatih secara serius untuk membaguskan tulisannya. Tugas lain adalah membuat ragam iluminasi/ornamen dan medium berwarna yang menerangkan hurufhuruf/ kata-kata

e. Langkah kelima

Tahap ini merupakan periode tingkat muailimin dimana pelajar memiliki buku-buku tulis, Riqeeah dan Tsulus. Studi kaligrafi/khat pada 
periode ini merupakan studi atas dasar kesadaran dan ketelatenan, dibawah bimbingan dan pengarahan yang datang dari perasaan pentinganya kaligrafi/khat dan pentingnya memperelok tulisan. Disiapkan untuk digunakan latihan setelah diajarkan karena kaligrafi/khat telah dibiasakannya melalui pemahaman dan indera

f. Langkah keenam

Pada tahap keenam ini titik-titik kelemahan terdapat pada pulpennya. Misalnya, dalam cara memiringkan/memanjangkan goresannya, sebab peserta didik kelas satu dan dua masih membutuhkan pengarahan dalam menulis dengan pulpen yang baik. Pedidik harus selalu memperhatikan ujung pelatuk kalam kayu/bambu, sehingga keserasian potongannya senantiasa terjaga. Oleh karena itu, pendidik selalu membawa contoh kalam tersebut untuk diperhatikan peserta

didiknya. Setiap kali hendak menulis, keserasian potongannya harus dicek. Jika umur kalam tambah menua ukurannya memendek. Saat itulah kita segera merautnya untuk meyakinkan bahwa ujung pelatuknya tetap bagus dan tulisan dapat digoreskan dengan indah. Keterangan dan koreksian harus berdasarkan "ukuran titik" sehingga pendidik menulis huruf dan kalimat di papan tulis dan buku peserta didik selalu di ukur dengan "ukuran titik" tersebut. Potongan kalam untuk setiap materi adalah seukuran dan yang digunakan untuk menulis, latihan dan koreksi misalnya peserta didik menulis naskhi/Riq"ah seukuran $4 \mathrm{~mm} / \mathrm{lebih}$, maka pendidik pun mengoreksi dengan mata pena selebar itu. Setiap peserta didik memerlukan dorongan agar tulisannnya tambah berkembang, tanpa dorongan seperti ini, praktek pengajaran menjadi tidak sempurna, seperti halnya mendemontrasikan huruf-huruf yang indah akan mendorong minat peserta didik untuk maju dengan perasaan bahagia karena berhasil memperindah tulisannya, ini pun merupakan motivasi untuk menambah kemajuan.

\section{Evaluasi Pembelajaran Kaligrafi}

Evaluasi dalam pembelajaran kaligrafi Arab dilakukan sebelum kegiatan pembelajaran berlangsung, hal ini dapat membantu guru untuk melihat kemampuan awal murid. Evaluasi juga dilakukan ditengah tengah kegiatan pembelajaran.

Guru membenarkan tulisan murid dengan buku mereka yang telah dipersiapkan, dan tidak mengoreksi dikertas kertas usang yang telah tulis, karena itu sama dengan tidak adanya hormat murid kepada guru dari satu 
sisi. Tidak adanya penghormatan pada materi kaligrafi Arab disisi lain, bahkan tidak mampu mengambil manfaat dari koreksi kesalahan. Koreksi hendaknya dengan tinta merah dan jangan sama dengan warna tinta murid. Dan koreksi dengan menggunakan pena murid untuk membantu guru mengenal murid.

Evaluasi tersebut dapat membantu guru dalam mengambil langkah pembelajaran selanjutnya. Selain itu evaluasi dapat dilakukan diakhir pembelajaran, seperti UTS dan UAS, dengan memberikan nilai yang sesuai dengan kemampuan menulis siswa. Dan ada baiknya jika guru memberikan penghargaan untuk penyemangat siswa dalam belajar ${ }^{11}$

\section{Pengertian Kitabah}

Kitabah adalah suatu kegiatan yang produktif dan ekspresif, dalam kegiatan ini seorang penulis harus terampil dalam menggunakan grafologi, struktur bahasa dan kosakata. Maharah kitabah ini berguna untuk merekam, mencatat, melaporkan, meyakinkan menginformasikan serta mempengaruhi pembaca. tujuan pembelajaran dapat diraih dengan baik oleh peserta didik yang mampu menyusun dan merangkai ungkapan hati serta mengemukakan dengan tulisan secara jelas, lancar dan komunikatif. ${ }^{12}$

Sedangkan menurut Abdul Hamid mengemukakan bahwa kemahiran menulis mempunyai tiga aspek yaitu:

1. Kemahiran membentuk huruf dan penguasaan ejaan

2. Kemahiran memperbaiki khot

3. Kemahiran melahirkan fikiran dan perasaan dengan tulisan. ${ }^{13}$

Dari beberapa pendapat di atas, pada intinya al-maharah al-kitabah dalam pembelajaran bahasa Arab adalah kemahiran yang melahirkan fikiran dan perasaan dengan tulisan. Tetapi, dari kenyataan yang kita lihat banyak sekali orang yang mampu menulis bahasa Arab dengan bagus dan orang tersebut tidak memahami makna kalimat yang telah ditulis. Oleh karena itu, dalam menulis menulis bahasa Arab terdapat dua aspek kemampuan yang harus dikembangkan yaitu kemampuan untuk menulis dengan benar dari segi tulisan, susunan dan tanda baca. Kemampuan

${ }^{11}$ Fauzi Salim Afifi, cara mengajar kaligrafi, dialihbahasakan oleh Didin Sirajudin, (Jakarta: darul Ulum Press, 2009), hlm.107

12 Anwar Efendi, Bahasa dan Sastra dalam Berbagai Perspektif, (Tiara Wacana: Jogjakarta), hal. 327

${ }^{13}$ Abdul hamid dkk, Pembelajaran Bahasa Arab, (Malang: Misykat, 2012), hal.181 
yang kedua yaitu kemampuan mengungkapkan ide, gagasan, pikiran dan perasaan menjadi sebuah tulisan bahasa Arab yang benar.

Maharah al-kitabah merupakan penerapan kemampuan dan keterampilan berbahasa yang rumit karena dengan cara menulis seseorang akan mengaplikasikan dua kemampuan berbahasa secara bersama-sama yaitu kemampuan aktif dan kemampuan produktif. Keterampilan menulis dalam pelajaran bahasa Arab dimulai dari pembelajaran menulis dasar yaitu pengetahuan dengan tata cara menulis, menyambung huruf, menulis kata, menulis kalimat, menulis tanpa lihat teks dan mengungkapkan ide serta gagasan dalam bentuk tulisan. ${ }^{14}$

\section{Tujuan Pembelajaran Kitabah}

Menurut Syahatah dalam Abdul Hamid, tujuan pembelajaran Kitabah adalah

1. Agar siswa biasa menulis arab dengan benar.

2. Agar siswa mampu mendeskripsikan sesuatu yang dilihat atau di alami dengan cermat dan benar

3. Agar siswa mapu mendeskripsikan sesuatu dengan cepat

4. Melatih siswa untuk menfekspresikan pikirannya dengan bebas

5. Melatih sisiwa memilikh kosakata dengan kalimat yang sesuai dengan konteks kehidupan .

6. Agar siswa terbiasa berfikir dengan mengekspresikan dalam tulisan dengan cepat

7. Melatih siswa mengekspresikan ide, pikiran, gagasan, dan perasaan, dalam ungkapan Bahasa Arab yang benar, jelas terkesan dan imajinatif

8. Agar siswa cermat dalam menulis dalam menulis Bahasa Arab dalam berbagai kondisi

9. Agar wawasan siswa semakin luas serta terbiasa berfikir logis dan sistematis. $^{15}$

Dalam mengajar keterampilan menulis guru harus mengajarkannya secara bertahap mulai dari tahap yang rendah kemudian tahap yang lebih tinggi.

Berikut ini adalah prinsip-prinsip mengajar keterampilan menulis:

${ }^{14}$ Khoirotun Nieemah Khat Dalam Menunjang Kemahiran Kitabah Bahasa Arab. Jurnal Dar el-ilmi Vol.5 No.2 Oktober 2018, diakses tanggal 21 Oktober 2019. Hal. 268.

${ }^{15}$ Hasan Syahatah, Ta'lim al-Lughoh al-Arobiyah Baina an-Nazhariyyah wa alTathbiq, (al-Qahirah: alDar al-Mashriyah al-Lubnaniyah, 2002). Hal. 242. 
1. Guru harus menentukan tema yang jelas

2. Tema yang digunakan dianjurkan dari kehidupan nyata atau pengalan langsung dari peserta didik, contoh tema tentang piknik, perayaan atau tema diambil dari pengalaman tidak langsung seperti film atau gambar.

3. Pembelajaran insya' harus dikaitkan dengan qowa'id dan muthola'ah karena insya ${ }^{e c}$ adalah media yang tepat untuk mengimplementasikan qowa'id yang idenya diperoleh dari muthola'ah

4. Setelah selesai insya' guru harus mengoreksi pekerjaan peserta didik, hal ini dilakukan untuk mengetahui kesalahan tulisan peserta didik dan diharapkan peserta didik tidak mengulangi kesalahan tulisannya

5. Dalam mengoreksi kesalahan, sebaiknya diurutkan berdasarkan kepentingannya dan hendaknya dibahasa dalam pelajaran khusus. ${ }^{16}$

Dalam mengajarkan maharah al-kitabah seorang guru harus menguasai teknik dan diharapkan dengan teknik tersebut dapat mempengaruhi peseta didik dalam mencapai tujuan pembelajaran yang telah ditetapkan. Berikut ini akan dijelaskan prosedur dan teknik pengajaran maharah al-kitabah:

1. Keterampilan sebelum menulis huruf

Pada tahap sebelum menulis huruf, seorang guru melatih peserta didik tata cara memegang pena dan meletakkan buku di depannya. Selain itu, peserta didik juga dilatih tentang cara menggaris seperti kemiringannya, cara memulai dan cara mengakhiri.

2. Pengajaran menulis huruf

a. Peserta didik dilatih menulis huruf-huruf secara terpisah setelah itu peserta didik dilatih menulis huruf sambung.

b. Peserta didik diminta menulis huruf-huruf secara tertib sesuai dengan urutan dalam abjad atau dengan mempertimbangkan kemiripan bentuk huruf.

c. Peserta didik diminta menulis huruf-huruf terlebih dahulu sebelum menulis suku kata dan menulis kata.

d. Peserta didik diminta menulis satu atau dua huruf baru setiap

16 Radliyah Zaenuddin, dkk, Metodologi \& Strategi Pembelajaran Bahasa Arab, (Yogyakarta: Pustaka Rihlah Group, 2005). Hal. 81. 
pelajaran.

e. Guru memberika contoh tulisan setelah itu peserta didik diminta untuk menulis di buku masing-masing.

Dalam pembelajaran maharah al-kitabah juga terdapat beberapa petunjuk umum yaitu sebagai berikut: ${ }^{17}$

1. Guru memperjelas materi akan diajarkan kepada peserta didik. Sebelum memulai aktifitas menulis guru hendaknya meminta peserta didik untuk mendengarkan dengan baik sehingga, peserta didik mampu membedakan pengucapan huruf dan kmengetahui bacaannya

2. Guru hendaknya menginformasikan kepada peserta didik tujuan pembelajaran yang akan dicapai

3. Guru hendaknya mengajarkan menulis dengan waktu yang cukup

4. Guru hendaknya mengajarkan keterampilan menulis dengan asas bertahap yakni dari yang sederhana dilanjutkan ke yang sulit, contoh:

a. Menyalin huruf

b. Menyalin kata

c. Menulis kalimat sederhana

d. Menulis sebagian kalimat yang ada dalam teks atau percakapan

e. Menulis jawaban dari pertanyaan-pertanyaan.

Seorang pelajar mahasiswa harus bisa menulis huruf-huruf dengan benar, jika tidak maka akan mengacaukan simbol symbol huruf atau kaedah kaedahnya, sehingga akan sulit untuk dibaca. Dan juga harus bisa merangkai kata-kata sesuai dengan aturan yang telah disepakati oleh para ahli Bahasa, jika tidak maka akan sulit untuk menerjemahkannya. Selain itu juga harus bisa memilih kata-kata yang tepat dan merangkaikan dengan sistimatis. Jika tidak maka akan sulit untuk memahami makna dan ide ide yang terkandung di dalamnya. ${ }^{18}$

${ }^{17}$ Abdul hamid dkk, Pembelajaran...., Hal. 49-50.

${ }^{18}$ Khadir, Al-Lughah, Hal. 277. 


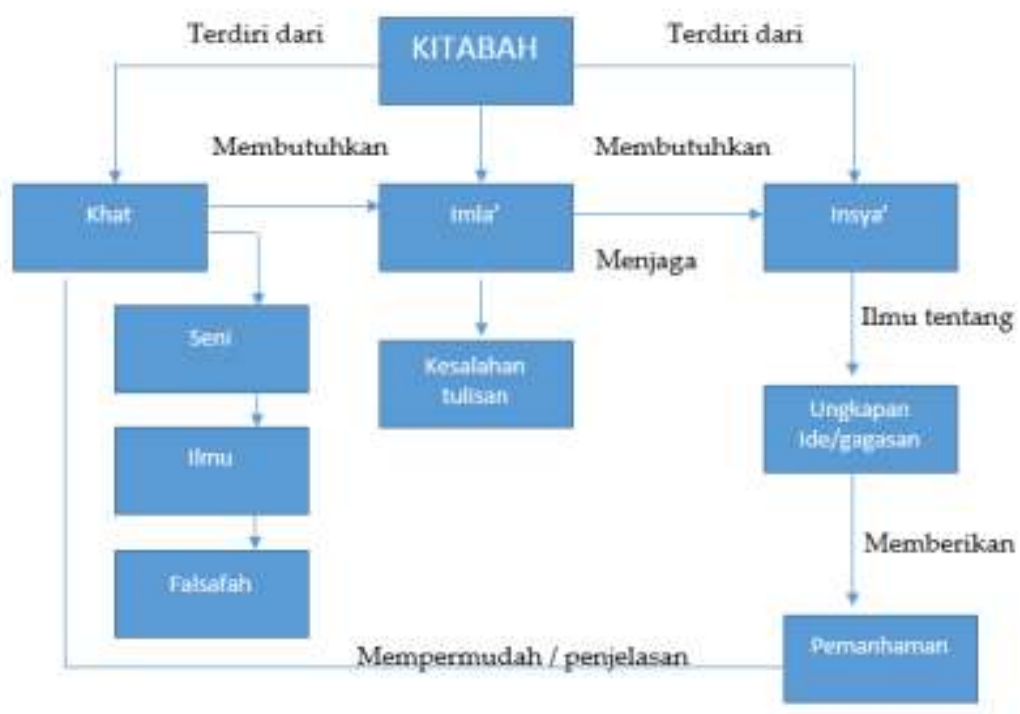

Dari tiga bagian Insya' adalah bagian terpening dalam kitabah. Imla' dan Khat merupakan bagian penyempurna Kitabah. Meski begitu, imla' menjadi penting untuk dipelajari agar para pelajar dapat mengungkapkan gagasannya dalam bentuk tulisan dengan baik dan benar. Hal ini akan memudahkan untuk dibaca, sehingga akan menjaga dari kesalahan makna karna jika tulisan salah akan menjauhkan kita dari makna yang diinginkan, hal ini akan menggagalkan komunikasi. ${ }^{19}$

\section{Kesimpulan}

Maharah al-kitabah merupakan penerapan kemampuan dan keterampilan berbahasa yang rumit karena dengan cara menulis seseorang akan mengaplikasikan dua kemampuan berbahasa secara bersama-sama yaitu kemampuan aktif dan kemampuan produktif.

Seorang pelajar mahasiswa harus bisa menulis huruf-huruf dengan benar, jika tidak maka akan mengacaukan simbol symbol huruf atau kaedah kaedahnya, sehingga akan sulit untuk dibaca. Dan juga harus bisa merangkai kata-kata sesuai dengan aturan yang telah disepakati oleh para

${ }^{19}$ Zakiyah mufida Pengembangan Bahan Ajar Khat Riq'ah Berbasis Kitabah Di Prodi PBA Semester II Skripsi, (UIN Sunan Kalijaga Yogyakarta 2016-2017) hlm 38 
ahli Bahasa, jika tidak maka akan sulit untuk menerjemahkannya. Selain itu juga harus bisa memilih kata-kata yang tepat dan merangkaikan dengan sistimatis. Jika tidak maka akan sulit untuk memahami makna dan ide ide yang terkandung di dalamnya.

Kaligrafi atau khat merupakan seni Islam yang mendapat perhatian dari para penulis sejarah dan kebudayaan. Kaligrafi mempunyai makna yang luhur, dan kedudukannya dalam kesatuan ruang dan waktu bagi kebudayaan Islam tidak diragukan lagi. Selama 14 abad lebih kaligrafi memainkan peran dominan yang mengisi hiruk pikuk perjalanan seni Islam secara menyeluruh. Masyarakat Arab sebelum Islam dikenal nomaden yang tidak memungkinkan hidup tumbuh dan berkembang bersama perkembangan kegiatan baca tulis, dan umumnya mereka mengenal tulisan dan bacaan hanya beberapa saat menjelang kedatangan Islam.

Teknik menulis kaligrafi bukanlah sesuatu yang asal-asalan, ada alasan tertentu dibalik setiap teknik, ada geometri yang akurat, ada kaidah-kaidah ketat di dalamnya, ada kesepakatan tidak tertulis diantara para seniman kaligrafi: seindah, sevariatif, serumit apapun kaligrafi, jangan sampai mengubah makna dan teks asli Alquran. Bahkan di awal perkembangan pencatatan Alquran ke dalam media tulis,

khat adalah proses interaksi peserta didik dengan pendidik dan sumber belajar kaligrafi untuk mempelajari tata cara menulis huruf-huruf Arab dengan benar sesuai dengan kaidah agar tulisan yang dihasilkan sesuai dengan standart yang ditentukan sehingga tulisan tersebut dapat diakui kebenarannya

\section{Daftar Pustaka}

Ahmadi, Abu dan Nur Uhbiyati. 2015. Ilmu Pendidikan, Jakarta: Renika Cipta.

Hermawan, Acep. 2014. Metodologi Pembelajaran Bahasa Arab, Bandung: PT Rosda Karya.

Afifi, Fauzi Salim. 1989. Pedoman Bagi Guru Kaligrafi, Terj. D.Sirojuddin AR, Jakarta: Depbinkat Lemka.

Afifi. Fauzi Salim, 2002. Cara Mengajar Kaligrafi (Pedoman Guru), Penerjemah D.Sirojuddin, Jakarta : Darul Ulum Press. 
al-Rahman, Abd. Abd Latif al-Dihan, Mamduh Nur al-Din, Abd Rabb AlNabiy. t.t. Mudzakkirah fi Tadris al-Kitabah. Jakarta: Ma"had al-Ulum al-Islamiyah wa al-Arabiyah bi Indunisiya.

AR, Didin Sirojuddin. 1983. Dinamika Kaligrafi Al-Quran, Terj. Ruh AlKhattul 'Arobi oleh Kamil Al-baba, Jakarta: Darul ‘Ulum Press

AR, Sirojuddin. 1992. Seni Kaligrafi Islam. Jakarta: Multi Kreasi Singgasana.

AR, Sirojuddin. 2014. Peta Perkembangan Kaligrafi Islam di Indonesia. Jurnal Al-Turas Vol. XX No. 1, Januari.

Niemah, Khoirotun. Implementasi Media Papan Mahir Bahasa Arab Dalam Pembelajaran Maharoh Kitabah. Jurnal Dar el-ilmi Vol.5 No.2 Oktober 2018, http://e-jurnal.unisda.ac.id/index.php/dar/article/view/1321

Sanjaya, Wina. 2006. Strategi Pembelajaran. Jakarta: Kencana Prenada Media Group.

Suaedy, Sholeh. 2011. Penerapan Berbagai Metode Pembeajaran Dalam Kegiatan Diklat. Surabaya : Artikel bdk surabaya. Kemenag.go.id.

Syahatah, Hasan. 2002. Ta'lim al-Lughah al-Arabiyah Baina an-Nazhariyyah wa at-Tathbiq, al-Qahirah: al-Dar al-Mashriyah al-Lubnaniyah.

Ulyan, Ahmad Fuad Mahmud. 1992. al-Maharah al-Lughowiyah, Mahiyatuha wa Turuqu Tadrisuha. Riyadh: Darul Muslim. 